\title{
Ewa Bińczyk, Epoka człowieka. Retoryka i marazm antropocenu, Wydawnictwo Naukowe PWN, Warszawa 2018, ss. 326
}

DOI: http://dx.doi.org/10.12775/RF.2019.015

W książce Epoka człowieka. Retoryka i marazm antropocenu Ewa Bińczyk porusza kwestie związane ze zmianą klimatyczną oraz przejściem od społeczeństwa ryzyka do społeczeństwa katastrofy [s. 132]. Najwięcej uwagi badaczka poświęca podkreśleniu wieloaspektowości tego procesu i możliwościom, jakie daje filozofom analiza kontrowersji pojawiających się wokół pojęcia antropocenu. Część prezentowanych w książce stanowisk została wyeksplikowana $\mathrm{w}$ innych publikacjach autorki $\mathrm{z}$ lat 2013-2017; niektóre z nich zostały poddane modyfikacjom i ukazały się ponownie w bardziej rozwiniętej formie.

Autorka wskazuje na wielość odniesień medialnych do tytułowego terminu ",antropogen”, jednak analizy - ze względu na wielowymiarowość problemu oraz ogromną liczbę wątków generowanych w narracji medialnej - zostają ograniczone do eksploracji dyskursów akademickich oraz niektórych przekazów o charakterze popularnonaukowym. Uwaga zostaje zogniskowana głównie na dziedzinach takich jak: geologia, klimatologia, nauki o systemie Ziemi, historia środowiska, geografia społeczna, antropologia, filozofia oraz socjologia [s. 17]. Jest to zabieg niezbędny z metodologicznego punktu widzenia.

Książka składa się z dziewięciu rozdziałów poprzedzonych przejrzystym wstępem oraz podsumowanych klarownym zakończeniem. Zwieńczeniem pracy jest imponująca bibliografia oraz bogaty indeks osobowy. Na uwagę zasługują również trzy aneksy. Pierwszy z nich prezentuje podstawowe dyskursy, jakie możemy wyróżnić w debacie dotyczącej zmiany klimatycznej oraz antropocenu. Dla każdej z wymienionych orientacji zostają wymienieni jej czołowi reprezentanci, wraz ze wskazaniem dyscyplin, w których się specjalizują. Jest to niezwykle 
pomocne dla czytelnika rozwiązanie, biorąc pod uwagę bardzo bogatą bibliografię. Kolejny aneks przytacza inne terminy określające zjawiska, które są opisywane pod szyldem antropocenu. Po raz kolejny mamy zatem ukłon w stronę czytelnika, który w innych opracowaniach mógł spotkać się ze zjawiskami definiowanymi jako antropogenu, jednak widniejącymi pod inną nazwą. Ostatnim aneksem jest słownik antropocenu oparty na porządku tematycznym, który ułatwia odnalezienie w pozostałych częściach pracy interesujących nas informacji, a jednocześnie podsuwa nam nowe tropy.

Recenzowana pozycja jest wielopłaszczyznowa. Zestawia ze sobą wyniki empirycznych badań przyrodoznawczych oraz pojęciowych analiz filozoficznych, co czyni ją wymagającą. Zgodnie $\mathrm{z}$ zamierzeniami sformułowanymi we wstępie autorka sumiennie rozwija swoją argumentację w kolejnych rozdziałach, wykazując się zarówno kompetencją merytoryczną jak i retoryczną. Godne uwagi są nie tylko aneksy umieszczone na końcu pracy, ale i obszerne wyjaśnienia oraz definicje znajdujące się w przypisach. Mogą one okazać się nieocenioną pomoca, szczególnie w przypadku czytelników nieobytych z subtelnościami słownika filozoficznego, być przydatne dla reprezentantów odmiennych dyscyplin, a także studentów. Jednocześnie umieszczenie ich w przypisach pozwala na zachowanie klarowności i przejrzystości wywodu.

Niezwykle ważną funkcją książki, która powinna zostać wyeksponowana, jest jej potencjał dialogiczny. Filozofia oraz przyrodoznawstwo od lat ścierają się w nierównej walce o pozycję oraz społeczny szacunek, tymczasem stanowią współbieżne narracje. Nauki te co prawda posługują się odmiennymi metodami oraz słownikami, jednak dotykają tych samych problemów. W obliczu impasu klimatycznego oraz szeroko opisywanego przez autorkę marazmu stajemy przed koniecznością współpracy i integracji badaczy z różnych dziedzin.

W książce tej istotna jest jednak nie tylko retoryka. Debaty toczone wokół pojęcia antropocenu mają również głęboki wymiar egzystencjalny, co wielokrotnie podkreśla sama autorka. Jest on związany nie tylko z kwestią przetrwania ludzi jako gatunku. Zmiana klimatyczna i odpowiedzialność spoczywająca na człowieku, który zyskał sprawczość w wymiarze geologicznym, sprawia, że niezbędna staje się redefinicja pojęcia wolności. Autorka wskazuje, że dotychczas ludzka wolność i sprawczość były budowane w opozycji do natury. Nieustanne przeciwstawianie się jej siłom wzbudzało w ludziach poczucie niezależności od otaczających czynników zewnętrznych, często było również wspierane przez tak zwaną biofobię, usiłującą przedstawić naturę jako zasób oraz wrogą siłę [s. 125].

Chociaż książka nie podejmuje tego wątku, warto podkreślić, że źródeł ludzkiej pychy możemy doszukiwać się już w dewizie zawartej 
w Księdze Rodzaju: „Uczyńmy człowieka na Nasz obraz, podobnego Nam. Niech panuje nad rybami morskimi, nad ptactwem powietrznym, nad bydłem, nad ziemią i nad wszystkimi zwierzętami pełzającymi po ziemi! (Rdz 1, 26)". Panowanie szybko zmieniło się w szaleńczą eksploatację naszej planety. Ludzkość zapomniała, że władza niesie ze sobą pewne konsekwencje. Jesteśmy bowiem odpowiedzialni za to, jaką planetę pozostawimy naszym dzieciom oraz wnukom. Recenzowana pozycja pokazuje, że bardzo często zapominamy o tej prawdzie.

Chciałabym teraz odnieść się do treści kolejnych rozdziałów, krótko omawiając najważniejsze wątki, jakie podejmują. Postaram się jednak nie odkrywać wszystkich kart i pozostawić pewien niedosyt, który może zachęcić do lektury recenzowanej pracy.

Rozdział pierwszy Zmiana klimatu - ignorowane wyzwanie pełni funkcję wprowadzającą. Zostaje w nim przedstawiona krótka historia badań nad klimatem oraz zmianą klimatyczną. Autorka zauważa, że diagnozowanie zmian klimatycznych jest ogromnym wyzwaniem, wymaga bowiem konsolidacji wiedzy pozyskiwanej w ramach różnych paradygmatów. Podejście interdyscyplinarne stanowi ogromny walor, analizowane problemy są często rozpatrywane pod różnym kątem i dają czytelnikowi cenną wiedzę. Niektórych zagadnień nie sposób jednak zrozumieć, gdyż są podejmowane $w$ ramach jednego wąskiego podejścia czy specjalności. Wyzwaniem staje się integracja wyników badań zbieranych przy użyciu odrębnych metod badawczych. Uczeni posługujący się odmiennymi słownikami często nie potrafią komunikować się ze sobą w efektywny sposób. Jak wskazuje autorka w rozdziale siódmym, zamieszanie terminologiczne sprzyja podmiotom mającym na celu wytwarzanie wątpliwości wokół debaty o antropocenie. Tymczasem środowisko naukowe reprezentuje $\mathrm{w}$ tej kwestii nad wyraz spójny pogląd. Na poparcie tezy o antropogenicznym charakterze zamian klimatu badaczka wnikliwie analizuje $\mathrm{w}$ rozdziale pierwszym kolejne raporty IPCC. Według cytowanych przez nią wyników raportu IPCC z roku 2014, który został stworzony przy współpracy około 800 badaczy reprezentujących różne orientacje teoretyczne, "na poziomie $95-100 \%$ [...] zmiany klimatyczne mają charakter antropogeniczny" [s. 38].

Rozdział drugi, zatytułowany Impas klimatyczny, wskazuje na słabości paryskiego porozumienia klimatycznego, a także ukazuje smutny obraz społeczeństwa, które $\mathrm{w}$ obliczu zachodzących zmian przyjmuje postawę bierną i apatyczną. Skąd wynika marazm? Autorka przytacza badania prowadzone przez Kari Marie Norgaard. Poszukuje ona przyczyn ignorowania przez ogół społeczeństwa zmian, które zachodzą na jego oczach. Innowacyjność jej podejścia przejawia się w poszukiwaniu ponadjednostkowych mechanizmów negowania zmiany klimatycznej. Problem denializmu okazuje się problemem globalnym. Co ciekawe, nie chodzi tu wcale o zwykłą ignorancję. Wielu zdaje sobie sprawę z powa- 
gi sytuacji, jednak z braku przestrzeni, w której mogliby wyrazić swój sprzeciw wobec postępującej degradacji środowiska naturalnego, pozostają oni bierni. Wiąże się to z poczuciem bezradności wobec tak daleko idących zmian. Powstrzymanie problemu zmiany klimatycznej wykracza poza możliwości indywiduów, wymaga interwencji na poziomie polityki oraz globalnej gospodarki.

Rozdział trzeci przedstawia źródła oraz ewolucję debaty dotyczącej antropocenu. Polemiki toczą się zarówno wokół samej nazwy, jak i mierników, które miałyby jasno określić, kiedy ludzkość zapoczątkowała nową epokę geologiczną. Precyzyjne określenie początków antropocenu okazuje się kluczowe dla wskazania, kto odpowiada za zainicjowanie tak daleko idących zmian w środowisku. Autorka, za Andresem Malmem i Alfem Hornborgiem, podkreśla, że ogromne znaczenie w tej kwestii ma także język, którym posługują się reprezentanci nauk przyrodniczych, mówiąc o odpowiedzialności za antropocen. Chodzi tu przede wszystkim o tak zwane zabiegi naturalizujące, które próbują przypisać winę ekspansywnej naturze ludzkiej [s. 98]. Tego rodzaju praktyki legitymizują bierność wobec kryzysu, przed którym stajemy, uznając go za konieczny rezultat naszej bytności na tej planecie. Biorąc pod uwagę stawkę, o jaką toczy się gra, daremne próby oczyszczenia się z zarzutów wydają się jeszcze smutniejsze.

Rozdział czwarty zwraca uwagę na wielowymiarowy charakter debaty o antropocenie, tłumaczy również pojęcia kluczowe dla dalszej części wywodu, a także podejmuje krytykę podejścia antropocentrycznego oraz przekonania o wszechwładności ludzkiego gatunku. Punktem wyjścia dla autorki staje się teoria „potwornych problemów” Horsta W. Rittela, które stanowią efekt węzłowych zależności łączących rozmaite elementy i powodują nieoczekiwane konsekwencje. Badaczka uważa, że destabilizację klimatu możemy zaklasyfikować do tego rodzaju kategorii [s. 105]. Ponadto $\mathrm{w}$ rozdziale tym destabilizacja klimatu zostaje ujęta jako problem polityczny, ekonomiczny i etyczny. Wyczerpywanie się zasobów naturalnych doprowadzi w końcu do kryzysu ekonomicznego, a kraje dotknięte przez niedobory będą zmuszone do walki o kurczące się zasoby. Autorka zauważa, że mamy do czynienia z paradoksalną sytuacją. Najbardziej dotkliwe konsekwencje ponoszą nie najwięksi aktorzy polityczni czy ekonomiczni, lecz szerokie rzesze grup wykluczonych z procesu decyzyjnego. Chodzi o rozwijające się kraje Globalnego Południa. Pesymistyczny obraz dopełnia podrozdział Utrata natury, $\mathrm{w}$ którym możemy zapoznać się $\mathrm{z}$ danymi statystycznymi prezentującymi zatrważający krajobraz wyniszczenia globalnych ekosystemów i utraty bioróżnorodności. Staje się on pretekstem do rozważań na temat różnych modeli ochrony przyrody oraz jej naprawy [s. 120]. Niestety ludzkie przekonanie o własnej dominacji i wszechwładności nie idzie w parze z przyjęciem odpowiedzialności za powodowane straty. Wciąż 
brakuje nam silnego politycznego aktora, który mógłby działać na rzecz wyjścia ze stagnacji, w którą popadliśmy.

Rozdział piąty podejmuje wątki ekonomiczne i polityczne, które $\mathrm{w}$ debacie na temat antropocenu według wielu badaczy i badaczek powinny stanowić główny trzon refleksji. Scierają się tu ze sobą różne podejścia. Zwolennicy ekomodernizmu są orędownikami patrzenia w przyszłość z nadzieją. Rozwiązania kryzysu klimatycznego upatrują oni w postępie technologicznym, jednocześnie postulując rozbudowane modele uwzględniające konsekwencje, jakie za sobą pociągają. Niektórzy z nich, jak na przykład przywoływany przez autorkę Michael Shellenberger, zauważaja, że innowacje technologiczne nie zadziałaja, jeśli nie będą miały za sobą poparcia w postaci zmiany mentalności ufundowanej na bazie konsumeryzmu [s. 146]. Autorka uczciwie prezentuje również opozycyjną w stosunku do ekomodernizmu narrację, która podkreśla, że krytykowane podejście opiera się na daleko idących uproszczeniach. Jako alternatywę proponuje się natomiast działania postwzrostowe, odrzucające imperatyw nieustannej akumulacji kapitału oraz upartego dążenia do dalszego rozwoju technologicznego. Interesujące są również referowane $\mathrm{w}$ niniejszym rozdziale poglądy funkcjonującego w ramach orientacji ekomarksistowskich Jasona W. Moore'a. Proponuje on zastąpienie terminu "antropocen" przez „kapitałocen”, co miałoby dodatkowo wyeksponować rolę kapitalizmu w wywołaniu kryzysu środowiskowego. Moore twierdzi, że prawdziwymi sprawcami globalnego ocieplenia są oparte na wyzysku i paradygmacie nieskończonej akumulacji dóbr relacje władzy. W tym samym rozdziale autorka odwołuje się również do krytyków posthumanizmu oraz sformułowanej przez Brunona Latoura teorii aktora-sieci. Na pierwszy plan po raz kolejny wysuwa się zatem problem odpowiedzialności. Krytycy, tacy jak cytowany przez autorkę Hamilton, nie godzą się na rozpraszanie sprawczości poprzez odwołania do aktorów pozaludzkich. Badaczka odnosi się jednak sceptycznie do tak sformułowanych zarzutów. Trafnie zauważa, że ujmowanie sprawczości jako rozproszonej nie stoi na przeszkodzie, by pociągnać człowieka - gatunek - do odpowiedzialności za powodowane straty. Wręcz przeciwnie, wskazuje, że wyjątkowa wrażliwość podejścia Latoura pozwala na ujęcie problemu w szerokim kontekście [s. 165].

W rozdziale szóstym autorka zwraca uwagę na pojawiającą się w wielu dyskursach krytykę pojęcia zrównoważonego rozwoju - podejścia, które jest szeroko promowane $\mathrm{w}$ światowej polityce środowiskowej. Po raz kolejny w centrum zainteresowania znajduje się retory$\mathrm{ka}$, tym razem jednak badaczka odnosi się do metafor funkcjonujących w obrębie analizowanego dyskursu. Niestety, jak zauważa, wiele z nich wyczerpało się i po prostu nie przystaje do tak dynamicznie zmieniającego się świata. Podobnie jak paradygmat zrównoważonego rozwoju, 
który podchodząc do problemu zbyt wąsko, nie daje nadziei na wypracowanie dobrze funkcjonujących rozwiązań o charakterze systemowym.

Krytycyzm autorki sięga również znanych na całym świecie ruchów środowiskowych. Sojusz ekologii z liberalizmem gospodarczym przyniósł więcej szkody, niż mogliśmy podejrzewać. Przewożenie towarów na ogromne dystanse pociąga za sobą zgubną w skutkach emisję $\mathrm{CO}_{2}$. Promyk nadziei niosą jednak dalsze rozważania prowadzone $\mathrm{w}$ omawianym rozdziale. Łączą je próby przeformułowania humanistyki oraz nadzieje na przekształcenie ludzkich poglądów na działalność polityczną. Po raz kolejny dowartościowane zostają rozwiązania proponowane przez Latoura, propagujące wypracowanie nowych modeli pomocnych w formułowaniu postulatów o charakterze politycznym.

Rozdział siódmy pt. Retoryka dezinformacji obnaża retorykę stosowaną w czasie tak zwanych kampanii dezinformacyjnych, które mogą obrócić się przeciwko nauce jako takiej, przyczyniając się do spadku społecznego zaufania do naukowców oraz badaczy. Autorka wskazuje na konkretne przykłady tego rodzaju działań, między innymi próby ukrycia wyników badań świadczących o zgubnym wpływie palenia papierosów. Pokazuje również analogiczny proceder w dziedzinie klimatologii. Jednocześnie zdemaskowane zostają grupy interesów, którym opłaca się generowanie szumu informacyjnego oraz podsycanie nieufności wobec autorytetu uznanych badaczy klimatu. Zgodnie z tytułem książki po raz kolejny wybrzmiewa retoryka, zostają opisane stosowane przez think thanki chwyty i strategie, między innymi negowanie problemu, ignorowanie jego istoty czy odwoływanie się do idei postępu [s. 208].

W rozdziale ósmym autorka ochładza entuzjazm, z jakim wiele środowisk podchodzi do rozwiązań proponowanych przez tak zwanych inżynierów klimatu, ukazując, że w dłuższej perspektywie mogą one przynieść większe szkody, niż dotąd sądzono. Z jednej strony świadomość posiadania „planów awaryjnych” sprzyja dalszemu delegowaniu problemu w przyszłość, z drugiej, biorąc pod uwagę złożoność klimatu, możemy stwierdzić, że ingerencja w jednym obszarze może wywołać niespodziewane skutki w kolejnym. Trudno przewidzieć, dokąd zaprowadzą nas rozwiązania proponowane przez geoinżynierów. Autorka nie pozostawia suchej nitki także na zwolennikach inżynierii człowieka. Ich pomysły nazywa ponurym żartem [s. 239]. Trudno jednak brać poważnie propozycje przeprogramowania ludności na wegetarianizm i manipulacji układem odpornościowym w celu wywołania reakcji alergicznych po spożyciu czerwonego mięsa [s. 238].

Rozdział dziewiąty stanowi zdecydowaną krytykę retoryki stosownej przez technoentuzjastów, którzy starają się bronić stanowiska, że lekarstwem na szkody wywołane przez skutki uboczne aplikowania kolejnych innowacji technologicznych mogą być kolejne daleko idące rozwiązania o charakterze technologicznym. Szczególnie niebezpieczne 
wydają się uproszczenia stosowane przez lobbujących na rzecz geoinżynierii. Schematyczne przedstawienia relacji pomiędzy człowiekiem i środowiskiem zaciemniają obraz, wiodąc do formułowania nierealistycznych koncepcji z pogranicza fantastyki naukowej. Prowadzą również do dalszego wykluczania obywateli i obywatelek krajów Globalnego Południa. W tym rozdziale autorka staje się rzecznikiem mniejszości, której głosy są nieustannie ignorowane. Wskazuje, że bezczynność może mieć katastrofalne skutki dla nas wszystkich. Zostaje podkreślony również retoryczny wymiar, jaki niesie ze sobą samo pojęcie geoinżynierii. Nie wiemy, jakie rezultaty mogłaby przynieść praktyczna aplikacja proponowanych w jej duchu rozwiązań. Wielu przytaczanych przez autorkę badaczy jest z nią zgodnych - uznają oni projekty inżynierii człowieka oraz klimatu za utopijne [s. 257]. Co więcej, trudno nazywać je rozwiązaniami, gdyż jedynie maskują problem, dając tymczasowe złudzenie kontroli nad sytuacją. Jedna ingerencja tego rodzaju pociąga za sobą konieczność kontynuowania danej strategii w przyszłości. Nie można również zapomnieć o tym, że nie mamy możliwości przetestowania postulowanych ingerencji $\mathrm{w}$ praktyce na wystarczająco szeroką skalę. W narrację tę doskonale wpisuje się przytaczane przez badaczkę zjawisko „dylematu kontroli” [s. 265], związane z niemożliwością kontrolowania efektów wprowadzonych zmian.

$\mathrm{W}$ zakończeniu autorka podsumowuje wnioski płynące $\mathrm{z}$ przeprowadzonych w toku wywodu analiz. Wskazuje, że problem zmiany klimatu może być źródłem kolejnych inspirujących rozważań nie tylko dla filozofów. Wypunktowane zostają zidentyfikowane w toku badań dualizmy i napięcia na linii człowiek-przyroda, które - jak wskazuje autorka - są związane z próbami jednoczesnego kwestionowania antropocentryzmu i usiłowaniem dokonania redefinicji pojęcia natury.

Myślę, że badaczka sprostała niezwykle trudnemu zadaniu, jakim jest przedstawienie $\mathrm{w}$ uporządkowany sposób tak wielowątkowej debaty, jak ta tocząca się wokół pojęcia antropocenu i zmiany klimatycznej. Na pierwszy plan, zgodnie z zamierzeniem sformułowanym już we wstępie, wysuwają się rozważania dotyczące retoryki funkcjonującej w ramach analizowanego dyskursu. Na uznanie zasługuje udana próba połączenia ze sobą dwóch z pozoru odległych dziedzin - filozofii i przyrodoznawstwa. Podobnie jak rzetelne przedstawienie opozycyjnych poglądów i merytorycznie podejmowane polemiki z ich reprezentantami. Warto wskazać również na pomyślną obronę zaproponowanej przez Brunona Latoura teorii-aktora sieci.

Książki nie da się czytać z zachowaniem spokoju i obojętności wobec przedstawianych $\mathrm{w}$ niej zagadnień. Pomimo prezentowanych pomysłów na poprawę sytuacji i zreformowanie naszego podejścia do problemu zmiany klimatycznej praca ma silny wydźwięk pesymistyczny. Myślę, że warte rozwinięcia w oddzielnej publikacji byłyby również analizy 
obejmujące funkcjonujący w mediach głównego nurtu sposób wypowiadania się na temat kryzysu środowiskowego. Książka może z powodzeniem pełnić rolę popularyzująca filozofię, eksponuje bowiem potrzebę prowadzenia krytycznych analiz oraz włączania namysłu filozoficznego do refleksji nad zagadnieniami ważkimi społecznie i politycznie.

Agata Woźniak-Jakubiec Uniwersytet Mikołaja Kopernika ORCID: 0000-0002-8833-6531 e-mail: 259088@stud.umk.pl 